\title{
PEMBUATAN NATRIUM ALGINAT DARI ALGA COKLAT (Phaeophyta) DAN PENGARUH PENAMBAHANNYA PADA SIFAT ANTIBAKTERIAL SABUN MINYAK DEDAK PADI (RICE BRAN OIL)
}

The Production of Sodium Alginate from Brown Algae (Phaeophyta) and The Effect of Addition on Antibacterial Properties of Rice Bran Oil Soap

\author{
Muhammad Ilham Setyoaji*, Muhammad Subehi, Susanty, Ratri Ariatmi Nugrahani \\ Program Studi Teknik Kimia Universitas Muhammadiyah Jakarta \\ Jl. Cempaka Putih Tengah 27, Jakarta Pusat
}

Diterima 02 Februari 2019 / Disetujui 05 Februari 2019

\begin{abstract}
ABSTRAK
Indonesia adalah negara yang kaya berbagai sumber daya alam sehingga dapat menunjang pertumbuhan perekonomian. Sumber daya hayati Indonesia sangat melimpah seperti Sargassum sp yang merupakan salah satu jenis Alga coklat (Phaeophyta). Alginat adalah komponen utama penyusun dinding sel, terdiri atas garam-garam kalsium, magnesium, natrium dan kalium alginat. Tujuan penelitian ini adalah mensintesa Natrium Alginat (Na-Alginat), mempelajari pengaruh konsentrasi $\mathrm{NaOH}$, mengkarakterisasi dan mengidentifikasi, serta mengaplikasikannya sebagai pengemulsi, pendispersi sehingga mempengaruhi sifat antibakterial sabun padat dari Minyak Dedak Padi (Rice bran oil), MDP. Metodologi penelitian yang dilakukan adalah mengekstraksi Alginat melalui jalur asam dengan variabel konsentrasi $\mathrm{NaOH} 2 \%, 4 \%, 8 \%, 10 \%$, dan $12 \%$, pemecahan sel menggunakan $\mathrm{HCl} 1 \%$, ekstraksi dengan $\mathrm{Na}_{2} \mathrm{CO}_{3} 4 \%$, konversi menjadi asam alginat dengan penambahan $\mathrm{HCl} 10 \%$. Konversi Asam alginat menjadi Na-Alginat dilakukan dengan penambahan $\mathrm{NaOH}$. Penambahan IPA (Isopropil alkohol) dilakukan untuk pemurnian. Karakterisasi produk meliputi kadar air, pH, dan identifikasi produk dilakukan dengan menggunakan FTIR (Fourier Transform Infra Red). Selanjutnya dilakukan uji aplikasi sehingga mempengaruhi sifat antibakterial pada sabun padat MDP. Hasil penelitian menunjukan kondisi terbaik adalah pada penambahan konsentrasi $\mathrm{NaOH} 4 \%$ dengan rendemen sebesar 10,95\%, pH produk berkisar 5-9, kadar air sebesar 3,3\% - 36,67 \%. Hasil analisis FTIR menunjukan produk yang dihasilkan merupakan Na-Alginat dengan adanya 3 puncak spesifik, gugus $\mathrm{COO}$ asimetris, gugus hidroksil $\mathrm{OH}$, dan $\mathrm{COO}$ simetris. Hasil uji aplikasi penambahan Na-Alginat terhadap sifat antibakterial sabun padat dari minyak dedak padi menunjukkan hasil yang tidak efektif menghambat pertumbuhan bakteri.
\end{abstract}

Kata Kunci : Alga coklat, FTIR, Natrium alginat, Natrium hidroksida

\section{ABSTRACT}

Indonesia is a country with abundant natural resources that support its economic growth. One of the natural resources of Indonesia is Sargassum sp, a genus of brown algae (Phaeophyta). Alginate is the main constituent of the cell walls, is composed of calcium salts, magnesium, sodium, and potassium alginate. The purposes of this study were to synthesize Sodium Alginate, to analyze the effect of $\mathrm{NaOH}$ concentration, to characterize and identify, as well as to apply as emulsifier, dispersant therefore it

*Korespondensi Penulis:

Email : ilmuhammadham16@gmail.com 
affect an antibacterial properties of Rice Bran Oil bar soap, RBO. As the research method, the extraction of Alginate was conducted through the acid pathway with the concentration of $\mathrm{NaOH}$ varied into $2 \%, 4 \%, 8 \%, 10 \%$, and $12 \%$, cell disruption with $1 \%$ of $\mathrm{HCI}$, extraction with $4 \%$ of $\mathrm{Na}_{2} \mathrm{CO}_{3}$, and conversion into alginic acid with the addition of $10 \%$ of HCI. The conversion of alginic acid into Sodium Alginate was conducted by adding $\mathrm{NaOH}$. The addition of isopropyl alcohol was done for the purification. The product characterization was carried out on the $\mathrm{pH}$ and water content, while the identification was performed by using FTIR. Then, an evaluation was done for the application of antibacterial properties on RBO bar soap. The results of this study showed that the best condition was indicated from the addition of $4 \% \mathrm{NaOH}$ concentration with $10.95 \%$ yields, 5-9 $\mathrm{pH}$ level, as well as $3.3 \%$ - 36.67\% water content. The result of FTIR analysis indicated that the product obtained was Sodium Alginate with asymmetric group $\mathrm{COO}$, hydroxyl group $\mathrm{OH}$, and symmetric group COO. The evaluation result of Sodium Alginate on the antibacterial properties of rice bran oil bar soap indicated an ineffective result in inhibiting bacterial growth.

Keywords : Brown algae, FTIR, Sodium Alginate, Sodium Hydroxyde

\section{PENDAHULUAN}

Indonesia adalah negara penghasil rumput laut 3.082.113 ton/tahun yang merupakan $50 \%$ dari produksi dunia untuk jenis rumput laut Eucheuma, Gracilaria, Sargassum dan Kappaphycus (Hendrawati dan Ramadhan, 2017). Jenis rumput Sargassum sp yang merupakan salah satu jenis Alga coklat (Phaeophyta) adalah merupakan penghasil alginat. Alginat merupakan salah satu komponen utama penyusun dinding sel. Natrium alginat adalah bahan kimia yang banyak digunakan pada industri pangan, obat, kosmetik, tekstil dan sebagainya. Menurut Sinurat dan Marliani, 2017, Natrium alginate dibuat dengan metode ekstraksi alginat melalui tahapan demineralisasi, netralisasi, ekstraksi, filtrasi, presipitasi, dan pemucatan, sehingga menghasilkan rendemen berkisar $19 \%$. Helmiyati dan Aprilliza, 2017 menyatakan bahwa Natrium alginat diisolasi dari alga coklat dengan menggunakan aseton-metanol dan kloroform, dan dapat dipisahkan dari pigmen, lemak dan zat ekstraktif lainnya. Isolat natrium alginat dikarakterisasi, salah satunya dengan menggunakan FTIR. Sampai saat ini Indonesia masih mengimpor alginat dari beberapa negara seperti Perancis, inggris, RRC, Philipina, jerman, dan Jepang. Menurut Badan Pusat Statistik (2017) dari bulan Januari sampai Agustus kegiatan impor alginat yang masuk ke Indonesia sebanyak $1.044 .092 \mathrm{~kg}$ sebelumnya jumlah impor alginat Indonesai dari tahun 2013-2016 menurut BPS berturut - turut sebanyak $1.284 .513 \mathrm{~kg}, 1.268 .615 \mathrm{~kg}, 1.199 .765 \mathrm{~kg}$, dan $1.800 .127 \mathrm{~kg}$. Data tersebut menunjukan bahwa kebutuhan alginat di Indonesia cukup tinggi. Berbagai manfaat Alginat adalah sebagai pengemulsi, penstabil struktur dan peningkat viskositas produk-produk pangan, dalam industri farmasi digunakan sebagai penstabil dalam larutan dan pendispersi bahan padat, penambahan alginat pada produk kertas dapat meningkatkan rheologi coating dan mengontrol migrasi. Natrium alginat berukuran partikel nano yang ditambahkan ke dalam kain katun, mengakibatkan serat memiliki aktivitas antimikroba (Rinaudo, 2014). Partikel nanosilver dalam keadaan stabil di dalam matriks natrium alginat memiliki aktivitas antimikroba terhadap bakteri patogen yang signifikan, seperti Staphylococcus aureus, Enterococcus faecalis, Escherichia coli, Proteus vulgaris, Enterobacter cloacae (Kubyshkin, et al., 2016). Selanjutnya perlu dilakukan penelitian mengenai kemampuan Natrium alginat sebagai pengemulsi, penstabil, dan pendispersi yang diaplikasikan pada formula sabun dengan menggunakan bahan baku Dedak padi (Rice bran). Dedak 
padi adalah hasil samping penggilingan padi. Di dalam dedak padi terkandung minyak dedak padi, dimana terkandung di dalamnya asam lemak dengan ikatan $\mathrm{C}$ jenuh dan tidak jenuh, sehingga bisa digunakan sebagai bahan baku oleokimia dengan berbagai macam proses, seperti produk metil ester, epoksi minyak (Nugrahani ${ }^{a}$, et.al., 2017), hasil pembukaan cincin oksiran dari epoksi minyak dedak padi (Nugrahani ${ }^{b}$, et.al., 2017) disamping itu di dalam ekstrak minyak dedak padi terkandung pula berbagai bahan aktif, diantaranya penol yang mempunyai kemampuan sebagai antioksidan (Arab, et. al., 2011) dan penghambatan terhadap bakteri (Wanna, et al., 2016). Pertumbuhan bakteri yang sifatnya merugikan dapat dikendalikan dan dihambat oleh suatu senyawa antibakteri. Tujuan pemberian senyawa antibakteri adalah untuk mencegah penyebaran penyakit, mencegah terjadinya infeksi, serta dapat mencegah terjadinya pembusukan dan perusakan bahan yang disebabkan oleh mikroorganisme (Simon, 2012). Mekanisme penghambatan terhadap pertumbuhan bakteri oleh senyawa antibakteri dapat berupa perusakan dinding sel dengan cara menghambat pembentukannya atau mengubahnya setelah selesai terbentuk, perubahan permeabilitas membran sitoplasma sehingga menyebabkan keluarnya bahan makanan dari dalam sel, perubahan molekul protein dan asam nukleat, penghambatan kerja enzim, dan penghambatan sintesis asam nukleat dan protein (Prasetyo, 2016). Aktivitas antibakteri dari suatu zat dapat ditetapkan antara lain dengan cara mengukur diameter daya hambat bakteri di sekitar area yang mengandung zat antibakteri. Metode ini disebut dengan metode difusi. Metode ini digunakan untuk mengukur kepekaan bakteri terhadap suatu senyawa antibakteri. Semakin besar aktivitas antibakteri maka diamteter daya hambat semakin besar. Berdasarkan pengujian tersebut akan dicari konsentrasi optimum dalam menghambat pertumbuhan bakteri. Kekuatan zat antibakteri tergantung terhadap ukuran zona hambat yang dihasilkan. Semakin lebar ukuran zona hambat maka semakin kuat zat antibakteri tersebut. Klasifikasi kekuatan zat antibakteri berdasarkan ukuran zona hambat : > $20 \mathrm{~mm}$ (sangat kuat); 10-20 mm (kuat); 5-10 mm (sedang); <5 mm (lemah) (Prasetyo, 2016). Adapun tujuan penelitian ini adalah untuk mensintesa Natrium Alginat (Na-Alginat), mempelajari pengaruh konsentrasi $\mathrm{NaOH}$ terhadap Na-Alginat, mengkarakterisasi dan mengidentifikasi Na-Alginat, serta mengaplikasikannya sebagai bahan aditif pengemulsi, pendispersi yang mempengaruhi sifat antibakterial sabun padat dari Minyak Dedak Padi (Rice bran oil).

\section{Bahan dan Metodologi}

Bahan yang digunakan dalam penelitian ini adalah Sargassum sp, Aquadest, $\mathrm{Na}_{2} \mathrm{CO}_{3}$, $\mathrm{HCl}, \mathrm{NaOCl}, \mathrm{NaOH}$, IPA (Isopropil Alkohol), Minyak Dedak padi, Minyak Kelapa sawit, Asam stearat, etanol, gula, NaAlginat, BHT, EDTA.

Metodologi penelitian yang dilakukan adalah sebagai berikut :

\section{Proses Pembuatan Na-Alginat}

Menurut (Subaryono. 2015) Proses pembuatan Na-Alginat terdiri dari tahapan sebagai berikut Rumput laut (Sargassum sp.) kering ditimbang $2 \mathrm{~kg}$ dan dicuci dan direndam di dalam $\mathrm{HCl} 1 \%$ selama satu jam dengan perbandingan rumput laut dan air 1:30 (b/v). Ekstraksi menggunakan larutan $\mathrm{Na}_{2} \mathrm{CO}_{3}$ divariasikan dari $2 \%, 4 \%, 7,5 \%, 8 \%$, dan $10 \%$ melalui dua tahap. Tahap pertama adalah ekstraksi rumput laut selama 60 menit, suhu $\quad 50-70^{\circ} \mathrm{C}$ kemudian dilakukan penggilingan. Tahap kedua yaitu proses ekstraksi dengan kondisi yang sama. Selanjutnya proses penyaringan menggunakan alat vibrator screen (150 mesh). Larutan $\mathrm{NaOCl}$ ditambahkan ke dalam filtrat sebanyak $4 \%$ dari jumlah filtrat yang 
dihasilkan, diaduk sehingga warna pucat dan didiamkan satu jam. Asam alginat terbentuk karena penambahan larutan $\mathrm{HCl} 10 \%$ ke dalam filtrat sehingga $\mathrm{pH}$ sebesar 3 dan didiamkan selama satu jam. Asam alginat terbentuk disaring dan dicuci dengan alat vibrator screen dan dibilas dengan air. Proses pengendapan asam alginat menggunakan $\mathrm{NaOH} 10 \%$ yang ditambahkan pada gel asam alginat kemudian diaduk hingga homogen dan mencapai $\mathrm{pH}$ netral (6-7). Larutan alginat dimasukkan ke dalam IPA (isopropil alkohol) sambil diaduk hingga terbentuk serat natrium alginat. Serat tersebut diambil lalu dikeringkan di dalam alat pengering yang selanjutnya digiling dan diayak hingga menjadi tepung natrium alginat berukuran 100 mesh dan 80 mesh.

\section{Karakterisasi dan Identifikasi Natrium Alginat}

Analisis terhadap Natrium alginat meliputi Kadar Air dan $\mathrm{pH}$. Sedangkan identifikasi struktur menggunakan FTIR (Fourier transform infra red)

Proses Pembuatan Sabun Minyak Dedak Padi dengan Penambahan Natrium alginat

Asam stearat dilarutkan ke dalam minyak dedak padi, minyak kelapa sawit, dan BHT pada $60-80{ }^{\circ} \mathrm{C}$, tambahkan $\mathrm{NaOH} 30 \%$ sehingga homogen. Selanjutnya tambahkan gula, EDTA (yang telah dilarutkan dalam air), Natrium alginat ditambahkan hingga homogen. Tambahkan etanol pada suhu $60-$ $80{ }^{\circ} \mathrm{C}$ sehingga transparan dan parfum pada suhu $50-60^{\circ} \mathrm{C}$. Campuran dituang dalam cetakan, didiamkan sampai mengeras.

Preparasi Uji Hambat Pertumbuhan Bakteri Sabun Minyak dedak padi dengan penambahan Natrium alginat

Preparasi Uji Hambat Pertumbuhan Bakteri Sabun Minyak dedak padi dengan penambahan Natrium alginat, terdiri dari tahapan : Sterilisasi Alat dan Bahan; Pembuatan Larutan Fisiologis; Pembuatan Larutan Standard Mc Farland 1; Pembuatan
Media TSA, Larutan Media Trypticase Soy Agar (TSA); Pembuatan Media Agar Miring; Inokulasi Bakteri Staphylococcus aureusdan Eschericia coli; Uji Daya Hambat Antibakteri Pada Produk Sabun padat dari minyak dedak padi; Pertumbuhan bakteri pada media agar diamati lalu diukur diameter daya hambat di area cakram dengan menggunakan jangka sorong.

\section{HASIL DAN PEMBAHASAN}

Proses pembuatan Natrium alginat dapat dilihat pada Gambar 1
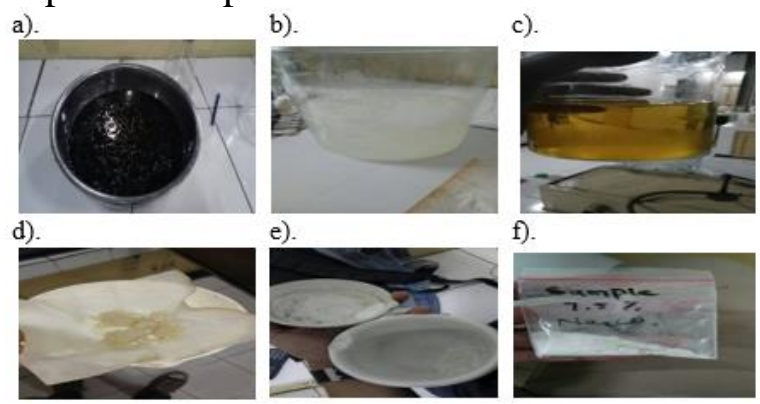

\section{Gambar 1.}

a. Perendaman Rumput laut dengan $\mathrm{HCl}$.

b. Konversi hasil Ekstraksi menjadi Asam Alginat.

c. Konversi Asam Alginat menjadi NaAlginat.

d. Penyaringan Na-Alginat yang telah dimurnikan.

e. Penepungan dan Pengeringan Na-Alginat.

f. Sample Produk Na-Alginat.

\section{Pengaruh Konsentrasi $\mathrm{NaOH}$ terhadap Rendemen Na-Alginat}

Pada penelitian ini proses yang digunakan adalah proses ekstraki asam dengan langkah mengubah hasil ekstraksi menjadi asam alginat lalu diendapkan dengan $\mathrm{NaOH}$ sehingga terbentuk Na-Alginat.

Tabel 1 menunjukkan dengan semakin tingginya Konsentrasi $\mathrm{NaOH}$, maka Rendemen Natrium alginat semakin tinggi, hal ini disebabkan karna pada proses pengndapan asam alginat menjadi $\mathrm{Na}-$ Alginat semakin tinggi konsentrasi $\mathrm{NaOH}$ 
rendemen yang dihasilkan cenderung lebih besar hal ini disebabkan pada konsentrasi tinggi maka akan semakin banyak ion $\mathrm{Na}$ yang dapat di konversi atau direaksikan dengan asam alginat menjadi Na-Alginat hal inidapat dilihat dari reaksi yang terjadi, reaksi sebagai berikut :

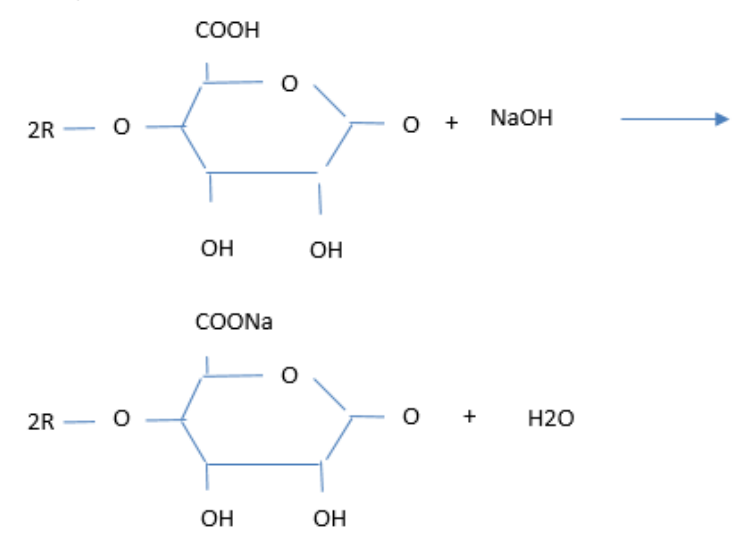

Tabel 1. Rendemen Natrium alginate yang diperoleh dari 20 g Rumput laut dengan berbagai Konsentrasi $\mathrm{NaOH}$ pada waktu ekstraksi 5 jam

\begin{tabular}{|c|c|c|c|}
\hline $\begin{array}{c}\text { Konsentrasi } \\
\text { NaOH }\end{array}$ & $\begin{array}{c}\text { Rendemen } \\
(\mathbf{\%})\end{array}$ & $\mathbf{p H}$ & $\begin{array}{c}\text { Kadar } \\
\text { air }\end{array}$ \\
\hline $\mathbf{2 \%}$ & 8,4 & 5 & 10 \\
\hline $\mathbf{4 \%}$ & 10,95 & 5 & 36,67 \\
\hline $\mathbf{8 \%}$ & 9,1 & 9 & 3,3 \\
\hline $\mathbf{1 0 \%}$ & 7,5 & 8 & 13,3 \\
\hline $\mathbf{1 2 \%}$ & 7,55 & 8 & 3,3 \\
\hline
\end{tabular}

Selanjutnya untuk mengetahui korelasi antara Konsentarsi $\mathrm{NaOH}$ dan rendemen dapat dilihat pada Gambar 2.

Berdasarkan pada Tabel 1 dan Gambar 2, konsentrasi $\mathrm{NaOH}$ berpengaruh terhadap hasil rendemen produk, pada konsentrasi $\mathrm{NaOH} 4 \%$ lah dihasilkan rendemen hasil tertinggi yakni sebesar $10,95 \%$ sedangkan yang terendah adalah pada konsentrasi $10 \%$ dengan hasil rendemen 7,5\%. Dari hasil analisa rndemen ini dapat dilihat bahwa titik terbaik konsentrasi $\mathrm{NaOH}$ adalah pada titik konsentrasi $4 \%$ dan regresi $\mathrm{y}=-0,0011 \mathrm{x}^{4}-$ $0,0631 \mathrm{x}^{3}-1,0411 \mathrm{x}^{2}+5,9929 \mathrm{x}$ dan $\mathrm{R}^{2}=$ 0,9946 dengan sumbu y sebagai rendemen dan sumbu x sebagai konsentrasi $\mathrm{NaOH}$.

Gambar 2. Pengaruh Konsentrasi $\mathrm{NaOH}$ terhadap rendemen Na-Alginat

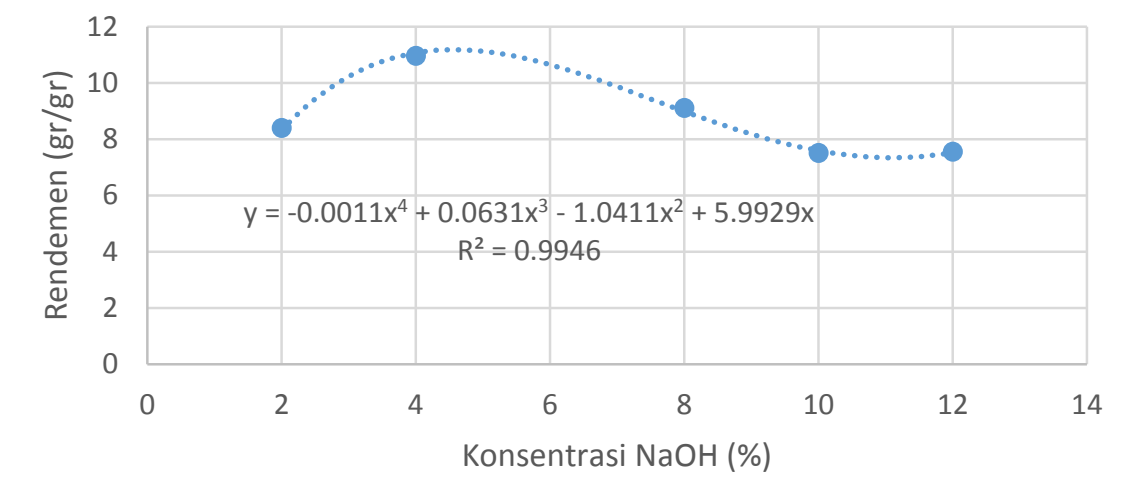

\section{Karakterisasi Produk Natrium Alginat Analisa pH}

Pada penelitian ini dihasilkan produk Natrium alginat dengan $\mathrm{pH}$ stabil pada kisaran 5-9 yang tertinggi pada konsentrasi 8 $\%$ sedangkan yang terendah pada konsentrasi $2 \%$ dan 4\%. Menurut Bahar et al. (2012) alginat stabil pada $\mathrm{pH} 5-10$, pada $\mathrm{pH}$ yang lebih tinggi mengakibatkan viskositas menjadi sangat kecil karena $\beta$-eliminatif terdegradasi. Hasil natrium alginat yang didapatkan sesuai dengan standar mutu industri pangan (food grade), yaitu berkisar antara 3,5-10.

\section{Analisa kadar air}

Kadar air Natrium alginat terbesar adalah pada $4 \% \mathrm{NaOH}$, yaitu sebesar $36,67 \%$ 
dan yang terkecil pada $8 \% \mathrm{Na}_{2} \mathrm{CO}_{3}$, yaitu pada sebesar 3,3\%. Menurut Jian et al. (2014) dan (Zailanie et al. 2001), pengendapan menggunakan isopropil alkohol lebih efektif jika dibandingkan dengan etanol, karena isopropil alkohol memiliki atom karbon yang mengikat gugus hidroksil (-OH) yang berikatan dengan dua karbon yang lainnya. Isopropil alkohol bersifat polar dan mampu membentuk ikatan hidrogen dengan molekul air. Gugus (-OH) pada isopropil alkohol mudah menarik molekul air dalam alginat dan mengakibatkan berbobot molekul tinggi, mengendap sehingga meningkatkan viskositas alginat. Konsentrasi isopropil alkohol semakin tinggi maka viskositas semakin tinggi karena penarikan kadar air menjadi lebih efektif.

\section{Identifikasi Produk Natrium Alginat}

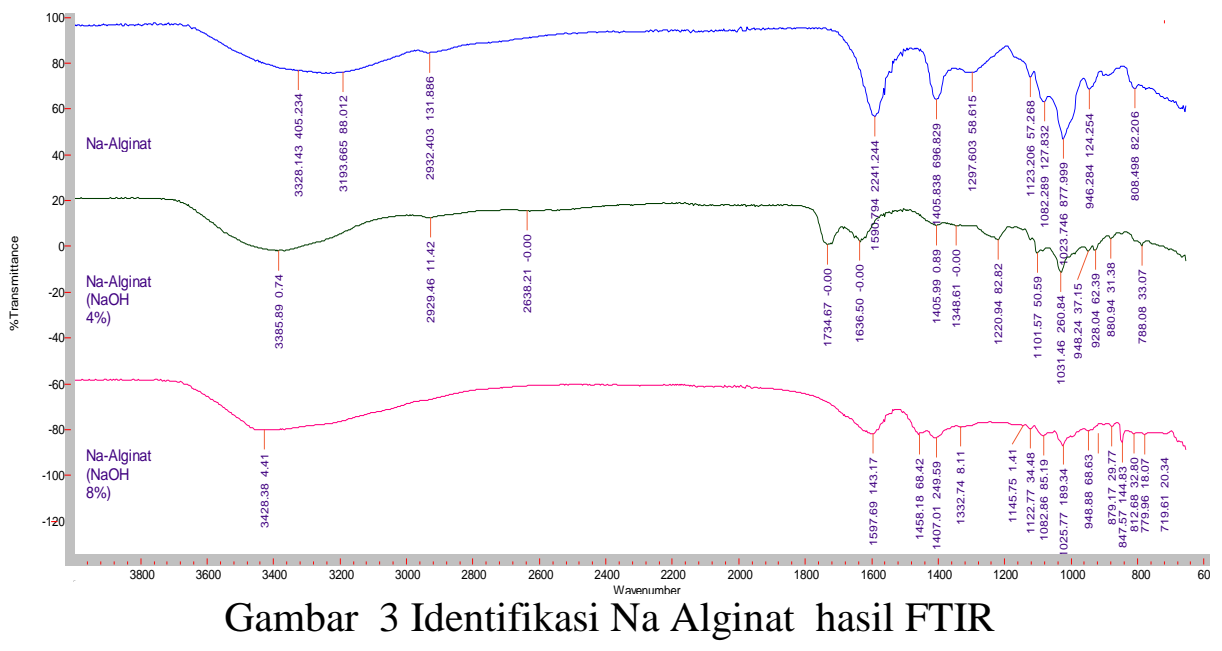

Tabel 2 Tabel Pembacaan hasil spectrum FTIR beberapa produk

\begin{tabular}{|c|c|c|c|c|c|}
\hline $\begin{array}{c}\text { Interpretasi } \\
\begin{array}{c}\text { Gugus Fungsi } \\
\left(\mathrm{cm}^{-1}\right)\end{array}\end{array}$ & $\begin{array}{c}\text { Referensi } \\
\text { Bilangan } \\
\text { Gelombang } \\
\left(\mathrm{cm}^{-1}\right)\end{array}$ & $\begin{array}{c}\text { Alginat } \\
\text { komersil } \\
\text { Referensi buku } \\
\left(\mathrm{cm}^{-1}\right)\end{array}$ & $\begin{array}{c}\text { Komersil } \\
\left(\mathrm{cm}^{-1}\right)\end{array}$ & & \multicolumn{2}{|c|}{\begin{tabular}{c} 
Alginat produk $\left(\mathrm{cm}^{-1}\right)$ \\
\cline { 5 - 6 }
\end{tabular}} & $3500^{\mathrm{a}}$ & $3425,58-$ & $3193,66-$ & 3385,89 & 3428,38 \\
\hline $\begin{array}{c}\text { Gugus hidroksil } \\
(\mathrm{O}-\mathrm{H})\end{array}$ & & 3448,72 & 3328,14 & & $8 \% \mathrm{NaOH}$ \\
\hline COO- asimetris & $1620^{\mathrm{a}}$ & $1604,77-$ & 1590,79 & $1636,5-$ & 1597,69 \\
& & 1620,21 & & 1734,67 & 1025,77 \\
\hline Karboksil (C-O) & $1023,4^{\mathrm{b}}$ & 1033,85 & 1023,75 & 1031,16 & 1025 \\
\hline
\end{tabular}




\begin{tabular}{|c|c|c|c|c|c|}
\hline \multirow{2}{*}{$\begin{array}{c}\text { Interpretasi } \\
\text { Gugus Fungsi } \\
\left(\mathrm{cm}^{-1}\right)\end{array}$} & \multirow{2}{*}{$\begin{array}{c}\text { Referensi } \\
\text { Bilangan } \\
\text { Gelombang } \\
\left(\mathrm{cm}^{-1}\right)\end{array}$} & \multirow{2}{*}{$\begin{array}{c}\text { Alginat } \\
\text { komersil } \\
\text { Referensi buku } \\
\left(\mathrm{cm}^{-1}\right)\end{array}$} & \multirow{2}{*}{$\begin{array}{c}\text { Alginat } \\
\text { Komersil } \\
\left(\mathrm{cm}^{-1}\right)\end{array}$} & \multicolumn{2}{|c|}{ Alginat produk $\left(\mathrm{cm}^{-1}\right)$} \\
\hline & & & & $4 \% \mathrm{NaOH}$ & $8 \% \mathrm{NaOH}$ \\
\hline $\begin{array}{l}\text { Sidik jari } \\
\text { guluronat }\end{array}$ & $890-900^{c}$ & $\begin{array}{c}887,26- \\
894,97\end{array}$ & 808,5 & 880,94 & 879,13 \\
\hline $\begin{array}{l}\text { CO stretching } \\
\text { uronic acid }\end{array}$ & $948,1^{b}$ & 948,98 & 946,28 & $\begin{array}{c}928,04- \\
948,24\end{array}$ & 948,88 \\
\hline COO- simetris & $1410^{\mathrm{a}}$ & 1419,61 & 1405,84 & 1405,99 & $\begin{array}{c}1407,01- \\
1458,18\end{array}$ \\
\hline
\end{tabular}

Keterangan: ${ }^{a} J u$ et al.(2002), ${ }^{b}$ Sergios et al. (2010), ${ }^{c}$ Bahar et al. (2012), Maharani A, dkk, 2017

Pada gambar 4 dan tabel 2 pada Alginat produk $4 \% \mathrm{NaOH}$ dan $8 \% \mathrm{NaOH}$ dapat disimpulkan bahwa natrium alginat hasil ekstraksi mempunyai gugus fungsi yang sama dengan natrium alginat komersial referensi buku dan pabrikan dan sesuai dengan standar menurut Ju et al. (2002) yaitu memiliki 3 puncak spesifik yang terdiri dari gugus hidroksil, COO- asimetris, dan $\mathrm{COO}-$ simetris. Sehingga dapat disimpulkan bahwa produk yang dihasilkan dari penelitian ini adalah Na-Alginat. pendispersi, pengental, dan pengemulsi terhadap sifat antibakterial Sabun Padat Minyak Dedak Padi

Sabun dengan bahan baku minyak dedak padi diharapkan dapat menghasilkan sabun yang mempunyai sifat antimikroba. Penambahan Natrium alginat sebagai pendispersi, pengental, dan pengemulsi, diharapkan mampu menghomogenkan campuran sehingga sabun yang terbentuk dapat menunjukkan sifat antibakterial. Tabel 3 menunjukkan komposisi campuran sabun

\section{Aplikasi Natrium alginat sebagai}

Tabel 3. Komposisi Sabun Minyak dedak padi dengan rasio volum

\begin{tabular}{|c|c|c|}
\hline Sampel & Minyak dedak padi : Minyak Kelapa Sawit & Gliserin : Natrium alginat \\
\hline 1 & $1: 6.5$ & \multirow{5}{*}{ Gliserin : 28} \\
\hline 2 & $2: 5.5$ & \\
\hline 3 & $3: 4.5$ & \\
\hline 4 & $4: 3.5$ & \\
\hline 5 & $5: 2.5$ & \\
\hline 6 & \multirow{5}{*}{ Minyak dedak padi : 7.5} & $5: 23$ \\
\hline 7 & & $8: 20$ \\
\hline 8 & & $10: 18$ \\
\hline 9 & & $12: 16$ \\
\hline 10 & & $14: 14$ \\
\hline
\end{tabular}

Selanjutnya hasil uji dari 10 komposisi pada yang terdapat pada Tabel 3, memberikan hasil uji penghambatan pertumbuhan bakteri sebagai berikut terdapat pada Tabel 4 dan Gambar 5.

Berdasarkan Tabel 4 dan Gambar 5 terlihat bahwa penambahan Na-Alginat pada pembuatan sabun padat dari minyak dedak padi tidak memberikan aktivitas antibakterial. Hal ini terlihat dari tidak adanya zona bening yang merupakan zona hambat pertumbuhan dari bakteri yang diujikan yaitu Escherichia coli dan Staphylococcus aureus dan ini disebabkan karena jumlah minyak dedak padi yang ditambahkan sangat sedikit. 
Tabel 4. Hasil uji hambat pertumbuhan bakteri dengan metode difusi:

\begin{tabular}{|c|c|c|c|c|c|c|}
\hline \multirow[t]{3}{*}{ Sampel } & \multicolumn{6}{|c|}{ Hasil Pengamatan Daya Hambat } \\
\hline & \multicolumn{3}{|c|}{$\begin{array}{l}\text { Staphylococcus aureus ATCC } \\
25923(\mathrm{~mm})\end{array}$} & \multicolumn{3}{|c|}{$\begin{array}{l}\text { Escherichia coli ATCC } 25922 \\
(\mathrm{~mm})\end{array}$} \\
\hline & 1 & 2 & 3 & 1 & 2 & 3 \\
\hline 1 & 6.00 & 6.00 & 6.00 & 6.00 & 6.00 & 6.00 \\
\hline 2 & 6.00 & 6.00 & 6.00 & 6.00 & 6.00 & 6.00 \\
\hline 3 & 6.00 & 6.00 & 6.00 & 6.00 & 6.00 & 6.00 \\
\hline 4 & 6.00 & 6.00 & 6.00 & 6.00 & 6.00 & 6.00 \\
\hline 5 & 6.00 & 6.00 & 6.00 & 6.00 & 6.00 & 6.00 \\
\hline 6 & 6.00 & 6.00 & 6.00 & 6.00 & 6.00 & 6.00 \\
\hline 7 & 6.00 & 6.00 & 6.00 & 6.00 & 6.00 & 6.00 \\
\hline 8 & 6.00 & 6.00 & 6.00 & 6.00 & 6.00 & 6.00 \\
\hline 9 & 6.00 & 6.00 & 6.00 & 6.00 & 6.00 & 6.00 \\
\hline 10 & 6.00 & 6.00 & 6.00 & 6.00 & 6.00 & 6.00 \\
\hline $\begin{array}{l}\text { Kontrol Positif } \\
\text { (Chlorampenicol } \\
1000 \mathrm{mg} / \mathrm{L})\end{array}$ & 20,58 & 19,53 & 16,83 & 26,78 & 27,17 & 27,73 \\
\hline Kontrol negatif (Air) & 6.00 & 6.00 & 6.00 & 6.00 & 6.00 & 6.00 \\
\hline Catatan: & \multicolumn{6}{|c|}{$\begin{array}{l}\text { Hasil tersebut di atas termasuk diameter kertas cakram berdiameter } 6 \\
\mathrm{~mm}\end{array}$} \\
\hline
\end{tabular}

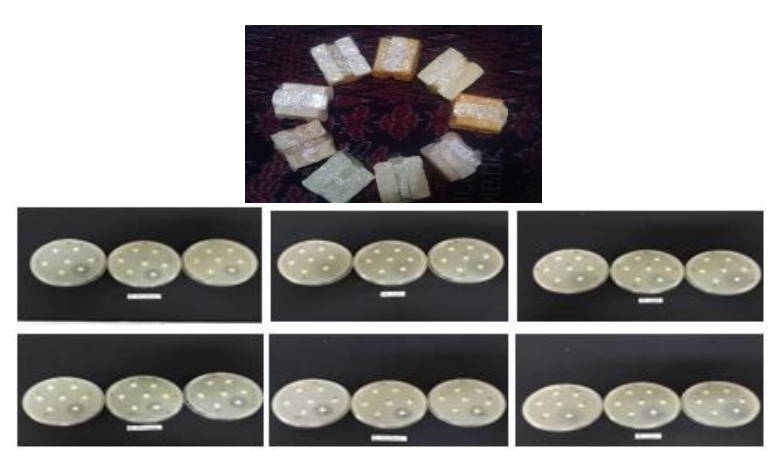

Gambar 4. Sabun Padat Minyak dedak padi dan hasil uji antimikroba

\section{DAFTAR PUSTAKA}

Arab, F., Alemzadeh, I., Maghsoudi, V., 2011. Determination of antioxidant component and activity of rice bran extract. Scientia Iranica, Volume 18, Issue 6

Bahar R, Arief A, Sukriadi. 2012. Daya hambat ekstrak Na-alginat dari alga coklat jenis Sargassum sp. terhadap proses pematangan buah mangga dan buah jeruk. Jurnal Indonesia Chimica Acta. 5(2): 22-31.

[BPS] Badan Pusat Statistik. 2017. Statisik Perdagangan Luar Negeri Indonesia (Import). Jakarta

Helmiyati and Aprilliza, M., 2017. Characterization and properties of sodium alginate from brown algae used as an ecofriendly superabsorbent. IOP Conf. Series: Materials Science and Engineering 188. doi:10.1088/1757899X/188/1/012019

Ju, HK, Kim, SY, Kim, SJ, Lee, YM. 2002. $\mathrm{pH} /$ temperature-responsive semi-IPN hydrogels composed of alginate and poly (N-Isopropylacrylamide). Journal of Applied Polymer Science. 83(3): 1128- 1139.

Jian HL, Lien XJ, Zhang WA, Zhang WM, 
Sun DF, Jiang JX. 2014. Characterization of fractional precipitation behaviour of galactomannan gums with etanol and isopropanol. Food Hydrocolloids. 40: 115- 121.

Kubyshkin, A., Chegodar, D., Katsev, A., Petrosyan, A., Krivorutchenko, Y., Postnikova.O., 2016. Antimicrobial Effects of Silver Nanoparticles Stabilized in Solution by Sodium Alginate. Biochem Mol Biol J., Volume 2(2).

Maharani AA, Husni A, Ekantari N. 2017. Karakteristik natrium alginat rumput laut cokelat Sargassum fluitans dengan metode ekstraksi yang berbeda. Jurnal Pengolahan Hasil Perikanan Indonesia. 20(3): 478-487.

Nugrahani, R.A ${ }^{\mathrm{a}}$, Redjeki, A.S., Mentari, Y., and Hasanah, M., 2017. The Effect of Temperature on Oxirane Oxygen in the Epoxidation of Rice Bran Oil Methyl Ester by Resin Catalyst. Advanced Science Letters Vol. 23

Nugrahani, R.A ${ }^{\mathrm{b}}$., Redjeki, A.S., Teresa, Y., Hidayati, N., 2017. SYNTHESIS OF COMPOUND-CONTAINING SULPHONIC ACID FROM EPOXIDIZED METHYL OLEIC OF RICE BRAN OIL AND LINEAR ALKYLBENZENE SULPHONIC ACID.

Prasetyo, H. T, 2016. Ekstrak Daun Cengkeh Sebagai Antibakteri Pada Sediaan Sabun Padat. Universitas Muhammadiyah Jakarta.

Rinaudo, M., 2014. Biomaterials based on a natural polysaccharide: alginate.TIP, Volume 17, Issue 1.

Sergios KP, Evangelos PK, Evangelos PF, Andreas AS, George ER, Fotios KK. 2010. Metal-carboxylate interactions in metal-alginate complexes studied with FTIR spectroscopy. Carbohydrate Research. 345: 469-473.

Simon, K. 2012. Penghambatan Sabun Mandi Cair Berbahan Aktif Triclosan Terhadap Pertumbuhan Staphylococcus Aureus di Daerah Babarsari, Sleman, Yogyakarta. Skripsi. Universitas Atmajaya Yogyakarta.

Sinurat, E dan Marliani, R., 2017. KARAKTERISTIK Na-ALGINAT DARI RUMPUT LAUT COKELAT Sargassum crassifolium DENGAN PERBEDAAN ALAT PENYARING. JPHPI, Volume 20, Nomor 2. Journal.ipb.ac.id/index.php/jphpi. DOI: http://dx.doi.org/10.17844/jphpi.v20i2. 18103

Subaryono. 2015. Pembuatan Tepung Puding Alginat. Balai Besar Riset Pengolahan Produk dan Bioteknologi Kelautan dan Perikanan, KKP.

Susanto T, Rakhmadiono S, Mujianto. 2001. Karakterisasi ekstrak alginat dari Padina sp. Jurnal Teknologi Pertanian. 2(2): 96- 109.

Tri Yuni Hendrawati dan Anwar Ilmar Ramadhan, 2017, Alkalynated Treated Cottonii (ATC) Chips from Eucheuma cottonii, South Sulawesi, Indonesia, Journal of Engineering and Applied Sciences 12 (Special Issue 7): 81478152, ISSN:1816-949X, Medwell Jornals.

Yani M. 1988. Modifikasi dan optimasi proses ekstraksi dalam rancang bangun proses tepung algin dari jenis Turbinaria ornata [skripsi]. Bogor: Fakultas Teknologi Hasil Pertanian, Institut Pertanian Bogor.

Zailanie K, Susanto T, Simon BW. 2001. 
Ekstraksi dan pemurnian alginat dari Sargassum filipendula kajian dari bagian tanaman, lama ekstraksi dan konsentrasi isopropanol. Jurnal Teknologi Pertanian. 20(1): 10-27.

Wanna, A., Singanusong, R., Wichaphon, J., Klangpetch. 2016. DETERMINATION $\mathrm{OF}$ ANTIOXIDANT AND ANTIMICROBIAL PROPERTIES OF HOMNIL RICE BRAN EXTRACTED BY ORGANIC SOLVENTS. Proceedings of The IRES 30th International Conference, Tokyo, Japan, 18th February 2016, ISBN: 97893-85973-35-2. 